\title{
Optimization and Application of a Quantitative Polymerase Chain Reaction Assay to Detect Diaporthe Species in Soybean Plant Tissue
}

Brian Kontz, Sajag Adhikari, Senthil Subramanian, and Febina M. Mathew, Department of Plant Science, South Dakota State University, Brookings 57007

\begin{abstract}
Kontz, B., Adhikari, S., Subramanian, S., and Mathew, F. M. 2016. Optimization and application of a quantitative polymerase chain reaction assay to detect Diaporthe species in soybean plant tissue. Plant Dis. 100:1669-1676.

Diaporthe caulivora and D. longicolla are the causal agents of stem canker of soybean (Glycine max L.). Accurate identification of stem canker pathogens upon isolation from infected soybean plants is difficult and unreliable based on morphology. In this study, two TaqMan probe-based quantitative polymerase chain reaction (qPCR) assays were optimized for detection of $D$. caulivora and $D$. longicolla in soybean plants. The assays used previously reported $D$. caulivora-specific (DPC-3) and $D$. longicolla-specific (PL-3) probe/primer sets. The sensitivity limit of the two assays was determined to be over a range of $100 \mathrm{pg}$ to $10 \mathrm{fg}$ of pure D. caulivora and

D. longicolla genomic DNA. The qPCR assays were validated with plant samples collected from commercial soybean fields. The PL-3 set detected D. longicolla in soybean plants collected from the fields (quantification cycle value $<35$ ), which was confirmed by isolation on potato dextrose agar (PDA). D. caulivora was detected only in low levels (quantification cycle value $<40$ ) by DPC- 3 set in a few of the symptomatic field samples, although the pathogen was not isolated on PDA. The qPCR assays were also useful in quantitatively phenotyping soybean plants for resistance to $D$. caulivora and $D$. longicolla under greenhouse conditions.
\end{abstract}

The Diaporthe/Phomopsis complex is known to cause several diseases on soybean (Glycine max (L.) Merr.). Among these, northern stem canker, caused by Diaporthe caulivora (Athow and Caldwell) Santos, Vrandečić, and Phillips (formerly known as D. phaseolorum var. caulivora), gained importance in the north-central United States in the late 1940s and early 1950s. Yield losses up to $50 \%$ were reported in the north-central United States during this time due to the planting of two susceptible varieties, 'Hawkeye' and 'Blackeye' (Fernández et al. 1999). With the elimination of these two susceptible varieties from soybean production, northern stem canker occurred only sporadically in the north-central United States (Backman et al. 1985).

The northern stem canker pathogen, D. caulivora, has been associated with seedling blight of soybean early in the growing season (Dunleavy 1969; Hildebrand 1956) and top dieback late in the season (Athow 1973; Hobbs et al. 1985). Chase (2011) suggests that, although stem canker infection can happen as early as 28 days following planting, the plants remained symptomless until late into the growing season. In general, symptoms of northern stem canker are not observed until the reproductive stages of flowering and pod development (Athow and Caldwell 1954; Chase 2011; Hobbs et al. 1985). The pathogen produces slightly sunken, reddish-brown lesions, usually at the base of lower leaf or branch nodes. As the disease progresses, lesions enlarge and form cankers, which are usually 2 to $10 \mathrm{~cm}$ long. In some cases, the lesions can girdle the stem and cause the soybean plant to die. D. caulivora survives as mycelium and perithecia in infested soybean residue or in the soil for many years. The pathogen may also be spread with infected seed (Backman et al. 1985; Fernández et al. 1999; Hobbs et al. 1985).

In addition to D. caulivora, D. longicolla (Hobbs) Santos, Vrandečić and Phillips is known to cause stem blight of soybean (Cui et al. 2009; Gebreil et al. 2015; Mathew et al. 2015b). The fungus was isolated from stem-canker-affected soybean samples in North

Corresponding author: F. M. Mathew; E-mail: febina.mathew@sdstate.edu

B. Kontz and S. Adhikari contributed equally to this article.

Accepted for publication 13 March 2016.

http://dx.doi.org/10.1094/PDIS-10-15-1204-RE

(C) 2016 The American Phytopathological Society
Dakota and South Dakota (Gebreil et al. 2015; Mathew et al. 2015b). The pathogen is also associated with black zone lines on the lower stems of mature soybean plants (Olson et al. 2015). In China, D. longicolla was solely associated with stem blight of soybean and the characteristic symptoms included dry rot, with discoloration at the branch or petiole, which caused plant wilt and death (Cui et al. 2009). Although D. longicolla is known to cause Phomopsis seed decay of soybean (Hartman et al. 1999) and can be isolated from discolored and nondiscolored mature soybean stems (Cui et al. 2009; Gebreil et al. 2015; Harrington et al. 2000; Mathew et al. 2015b; Olson et al. 2015), the role of the pathogen in the development of soybean stem disease is not certain. This implies that diagnosis of soybean stem canker based on symptoms and corresponding identification of causal agents is not always reliable, given that the symptomless infections by $D$. caulivora or $D$. longicolla may occur early in the season (Chase 2011; Li et al. 2009). In addition, multiple Diaporthe spp., including D. aspalathi Jansen, Castlebury, and Crous; D. sojae Lehman; D. gulyae Shivas, Thompson, and Young; D. longicolla; and D. caulivora, are reported to cause stem disease on soybean (Lehman 1922; 1923; van Rensburg et al. 2006; Mathew et al. 2015b) (F. Mathew and S. Markell, unpublished).

Generally, symptoms of the disease caused by Diaporthe spp. may vary with host variety and ecophysiology, geographic location, environmental conditions, and severity of infection (Kucharek et al. 1983; Timmer and Fucik 1976; Udayanga et al. 2014; Whiteside 1977). However, upon isolation of the causal fungus from the affected plant parts, accurate identification of the Diaporthe sp. is always difficult and unreliable based on morphology (van Rensburg et al. 2006). Recently, molecular phylogenies using DNA sequences of the ribosomal internal transcribed spacer (ITS) regions of the nuclear ribosomal RNA genes, translation elongation factor- $1 \alpha$ (EF- $1 \alpha)$ genes, and actin genes have been used to identify Diaporthe spp. (Gomes et al. 2013; Mathew et al. 2015a; Olson et al. 2015; Santos et al. 2011; van Rensburg et al. 2006).

Molecular detection methods have become increasingly important in disease diagnosis and management decisions because of high sensitivity and specificity. Quantitative polymerase chain reaction (qPCR) has been extensively applied in quantification and detection of numerous pathogens from plant, seed, and soil samples. For example, for detection of Diaporthe spp. on soybean seed, Zhang et al. (1997) designed three TaqMan primer-probe sets based on ITS sequences. The primer-probe set PL-5 amplified a 96-bp fragment within the 
ITS1 region of $D$. longicolla; $D$. caulivora; $D$. aspalathi; and $D$. sojae (Zhang et al. 1997). The other two primer-probe sets (PL-3 and DPC-3) amplified a 86-bp DNA fragment within the ITS2 region of $D$. longicolla and a 151-bp DNA fragment within the ITS2 region of $D$. caulivora, respectively (Zhang et al. 1997). However, these three TaqMan primer-probe sets were not tested on soybean plant tissues infected with stem canker pathogens by Zhang et al. (1997) to determine the applicability of the assays to identify the causal pathogens. The specific objectives of this study were to (i) evaluate the three TaqMan probe-based qPCR assays designed by Zhang et al. (1997) for detection of the two stem canker pathogens, D. caulivora and D. longicolla; (ii) optimize the qPCR parameters to maximize the sensitivity and specificity of the two pathogens in soybean plant tissue; (iii) directly quantify the two stem canker pathogens in infected soybean samples collected from commercial soybean fields and compare the efficiency with culture based isolation; and (iv) determine the potential of the qPCR assays to phenotype soybean plants for resistance to D. caulivora and D. longicolla under greenhouse conditions.

\section{Materials and Methods}

Optimization of the qPCR assays to detect $D$. longicolla and D. caulivora. The primers and probes used in these experiments were obtained from Zhang et al. (1997). The three probes were labeled with 5' 6-FAM, an internal ZEN quencher, and a 3' Iowa Black quencher. All primers and probes for this study were synthesized by Integrated DNA Technologies, Inc. (Coralville, IA).

To evaluate the qPCR assays, DNA was extracted from an isolate of D. longicolla (DP01-422) and two isolates of D. caulivora (DP99-030 and DP00-203). The three isolates (DP01-422, DP99-030, and DP00-203) were recovered from soybean plants symptomatic of stem canker randomly sampled from a commercial soybean field in South Dakota (Hamlin County) in 2010 (T. Chase, unpublished). To isolate the pathogens, the stem samples collected from the soybean field were washed with tap water for $2 \mathrm{~min}$, and pieces (approximately $1 \mathrm{~cm}$ long) were cut from the lesions of the infected stems. The pieces from each stem sample were surface disinfested in sodium hypochlorite $(0.05 \%)$ and then ethanol $(70 \%)$ for $1 \mathrm{~min}$ each, rinsed in sterile distilled water two times, and blotted between sterile paper towels. Four pieces were placed on potato dextrose agar (PDA; Becton, Dickinson and Company, Franklin Lakes, NJ). Plates were incubated at $25^{\circ} \mathrm{C}$ for 7 to 10 days under fluorescent light with a photoperiod of $12 \mathrm{~h}$ daily. Within 7 to 10 days, mycelial colonies appeared white, dense, and floccose. DNA was extracted from the mycelium scraped from the surface of 10-day-old culture growing on PDA using a Wizard Genomic DNA Purification Kit (Promega Corp., Madison, WI), following the manufacturer's instructions. The Diaporthe isolates were identified to species by amplifying and sequencing of the ITS region using ITS1 and ITS2 primers (White et al. 1990) prior to using the DNA of these isolates for qPCR assay.

To determine the optimal conditions for qPCR, three serial dilutions of $(1 / 1,000,1 / 10,000$, and $1 / 100,000)$ were prepared from the fungal DNA of the three Diaporthe isolates (DP01-422, DP99-030, and DP00-203). Diethylpyrocarbonate (DEPC)-treated water $(0.1 \%)$ without the DNA template was used as a negative control in the optimization study. The cross specificity of the primers were also tested using the three serial dilutions $(1 / 1,000,1 / 10,000$, and $1 / 100,000)$ prepared from the fungal DNA of the three Diaporthe isolates by using DPC-3 primers on the DNA of the isolate D. longicolla (DP01-422) and using PL-3 and PL-5 primers on the DNA of the two isolates of D. caulivora (DP99-030 and DP00-203). Each qPCR for the three primer-probe sets (PL-5, PL-3, and DPC-3) consisted of $1.6 \mu$ l of template DNA, $0.4 \mu \mathrm{l}$ of $10 \mu \mathrm{M}$ forward primers, $0.4 \mu \mathrm{l}$ of $10 \mu \mathrm{M}$ reverse primers, $0.4 \mu \mathrm{l}$ of ROX (Clontech Laboratories, Mountain View, CA), $7.2 \mu \mathrm{l}$ of autoclaved DEPC-treated deionized water, and $10 \mu \mathrm{l}$ of Takara Bio SYBR Premix Ex Taq (Tli RNase H Plus; Clontech Laboratories) in $20 \mu \mathrm{l}$ of total volume. The DEPC water was used in this study because autoclaving decomposes DEPC into ethanol and $\mathrm{CO}_{2}$, alleviating any potential inhibitory effects of this compound at the concentration used $(0.1 \%)$, which ensures clean, nuclease-free water for PCR. The amplifications were performed using a Stratagene Mx3000P qPCR system (Qiagen, Valencia, CA). Cycling parameters for qPCR were $95^{\circ} \mathrm{C}$ for $5 \mathrm{~min}$, followed by 40 cycles of $95^{\circ} \mathrm{C}$ for $15 \mathrm{~s}$ and $60^{\circ} \mathrm{C}$ for $1 \mathrm{~min}$ (Zhang et al. 1997).

To determine the optimum probe concentration for the three primer-probe sets (PL-5, PL-3, and DPC-3), five different concentrations $(50,100,150,200$, and $250 \mathrm{~nm})$ of the respective probes were prepared in DEPC-treated water. The goal was to use the minimum amount of probe without compromising detection efficiency. We expected that, if increasing the probe concentration does not reduce the cycle threshold $\left(\mathrm{C}_{t}\right)$ value at a given template concentration, then probe concentration is not limiting. Based on the results in the previous qPCR to determine the optimal probe concentration, DNA of the three Diaporthe isolates (DP01-422, DP99-030, and DP00-203) was diluted to $1 / 1,000$ concentration. The DPC-3 primer-probe set was used for amplification of the two isolates of D. caulivora (DP99-030 and DP00-203). The PL-3 and PL-5 primer-probe sets were used to amplify the isolate $D$. longicolla (DP01-422). DEPC-treated water without the DNA template was used as a negative control. Each qPCR for the three primerprobe sets (PL-5, PL-3, and DPC-3) consisted of $1.6 \mu$ l of template DNA, $0.4 \mu \mathrm{l}$ of $10 \mu \mathrm{M}$ forward primers, $0.4 \mu \mathrm{l}$ of $10 \mu \mathrm{M}$ reverse primers, $2 \mu \mathrm{l}$ of the respective probe, $4.4 \mu \mathrm{l}$ of DEPC-treated water, and $10 \mu \mathrm{l}$ of TaqMan Universal Master Mix II (Applied Biosystems, Life Technologies, Carlsbad, CA) in $20 \mu$ l of total volume. The amplifications were performed using a Stratagene Mx3000P qPCR system (Qiagen). Cycling parameters for qPCR were $50^{\circ} \mathrm{C}$ for $2 \mathrm{~min}, 95^{\circ} \mathrm{C}$ for $10 \mathrm{~min}$, followed by 40 cycles of $95^{\circ} \mathrm{C}$ for $15 \mathrm{~s}$ and $60^{\circ} \mathrm{C}$ for $1 \mathrm{~min}$ (Zhang et al. 1997). All reactions, including standards, were run in three replicates.

Amplification and reaction conditions for the qPCR assays. For amplification and for generating standard curves, qPCR assays using DPC-3 and PL-3 primer-probe sets (Zhang et al. 1997) for detection of $D$. caulivora and D. longicolla were performed using a Stratagene Mx3000P qPCR system (Qiagen). Each qPCR consisted of $1.6 \mu \mathrm{l}$ of template DNA, $0.4 \mu \mathrm{l}$ of $10 \mu \mathrm{M}$ forward primers, $0.4 \mu \mathrm{l}$ of $10 \mu \mathrm{M}$ reverse primers, $2 \mu \mathrm{l}$ of $100 \mathrm{nM}$ respective probe, $4.4 \mu \mathrm{l}$ of sterile distilled water, and $10 \mu \mathrm{l}$ of TaqMan Universal Master Mix II (Applied Biosystems, Life Technologies) in $20 \mu \mathrm{l}$ of total volume. Cycling parameters for $\mathrm{qPCR}$ of $D$. longicolla and D. caulivora were $95^{\circ} \mathrm{C}$ for $10 \mathrm{~min}$, followed by 40 cycles of $95^{\circ} \mathrm{C}$ for $15 \mathrm{~s}$ and $60^{\circ} \mathrm{C}$ for $1 \mathrm{~min}$ (Zhang et al. 1997). All reactions, including standards, were run in four replicates.

Prior to the DNA extraction, the D. longicolla isolate DP01-422 and $D$. caulivora isolate DP00-203 were grown in potato dextrose broth $(200 \mathrm{~g}$ of raw potato and $20 \mathrm{~g}$ dextrose in $1,000 \mathrm{ml}$ distilled water) at $22 \pm 2{ }^{\circ} \mathrm{C}$ for 10 to 14 days. DNA was extracted from lyophilized mycelium growing in potato dextrose broth using a Wizard Genomic DNA Purification Kit (Promega Corp.), following the manufacturer's instructions.

For the two qPCR assays, absolute quantification of DNA was accomplished using standard curves of known concentrations of DNA of the D. longicolla isolate DP01-422 and D. caulivora isolate DP00-203. The standard curves were generated using 1:10x serial dilutions of the Diaporthe isolates over five orders of magnitude (100 pg to $1 \mathrm{fg}$ ) and plotted as the log of DNA concentration versus the $C_{t}$ value, which represents the log-linear phase of the amplification growth curve. The $\mathrm{C}_{\mathrm{t}}$ values were determined at an arbitrarily set threshold of 0.05 . The PCR efficiency $(\%)$ was calculated as $\mathrm{E}=\left(10^{(- \text {slope })}-1\right) \times 100$ for each assay and the slope is derived from the plot of log of template DNA concentration versus $\mathrm{C}_{\mathrm{t}}$.

Application of the qPCR assays to detect $D$. longicolla and D. caulivora in soybean tissue. In this study, the DPC-3 and PL-3 primer-probe sets (Zhang et al. 1997) were employed for quantification of $D$. longicolla and $D$. caulivora in soybean plants. Two symptomatic soybean plants were sampled from a commercial soybean field with history of soybean stem canker in Hamlin County, SD in 2010. Two asymptomatic samples were also collected from the same field to serve as a negative control. For an additional negative control, surface-sterilized soybean seed were germinated on sterile filter paper 
towels in a sterile container. Soybean seed were incubated at $23^{\circ} \mathrm{C}$ for 14 days and these "axenic" seedlings were used as negative controls for subsequent qPCR tests. The axenic seedlings were spiked with a

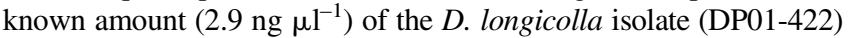
and $D$. caulivora isolate (DP00-203) to rule out any potential inhibitors that might be present in plant samples that can hamper pathogen detection by qPCR. About $100 \mathrm{mg}$ of each of the plant samples was ground in liquid nitrogen. Total DNA was isolated from each of the plant samples using the QIAquick DNA extraction kit (Qiagen) as per the manufacturer's instructions and quantified using a NanoDrop spectrophotometer (NanoDrop Technologies, Wilmington, DE). In the qPCR, DNA of the D. longicolla isolate (DP01-422) and D. caulivora isolate (DP00-203) was used as the positive control. DEPC-treated water without the DNA template was used as a negative control. The qPCR was performed in a reaction volume of $20 \mu \mathrm{l}$. Each qPCR consisted of $1.6 \mu \mathrm{l}$ of template DNA, $1.0 \mu \mathrm{l}$ of $10 \mu \mathrm{M}$ forward primers, $1.0 \mu \mathrm{l}$ of $10 \mu \mathrm{M}$ reverse primers, $2 \mu \mathrm{l}$ of $100 \mathrm{nM}$ respective probe, $4.4 \mu \mathrm{l}$ of sterile distilled water, and $10 \mu \mathrm{l}$ of TaqMan Environmental Master Mix (Applied Biosystems) in $20 \mu$ l of total volume. Cycling parameters for $\mathrm{qPCR}$ of $D$. longicolla and D. caulivora were $95^{\circ} \mathrm{C}$ for $10 \mathrm{~min}$, followed by 40 cycles of $95^{\circ} \mathrm{C}$ for $15 \mathrm{~s}$ and $60^{\circ} \mathrm{C}$ for $1 \mathrm{~min}$ (Zhang et al. 1997).

Fungal isolates, DNA isolation, and qPCR conditions. To determine the application of the two qPCR assays (Zhang et al. 1997) to directly identify $D$. longicolla and $D$. caulivora, pure cultures of 11 isolates of fungal pathogens, including $D$. caulivora and $D$. longicolla, that are associated with soybean and other hosts used were used (Table 1). Cultures of the Diaporthe spp. and other fungi were initially grown on PDA media (200 g of raw potato, $20 \mathrm{~g}$ of dextrose, and $10 \mathrm{~g}$ of agar in $1,000 \mathrm{ml}$ of distilled water) at $22 \pm 2^{\circ} \mathrm{C}$ for 10 to 14 days. These fungal isolates were purified by transferring hyphal tips to fresh plates of PDA for DNA extraction. DNA of the 11 isolates was extracted from lyophilized mycelium scraped from the surface of the purified culture growing on PDA using the FastDNA Spin Kit (MP Biomedicals, Solon, OH), following the manufacturer's instructions. DNA concentrations were determined using a NanoDrop spectrophotometer (NanoDrop Technologies, Wilmington, DE), and

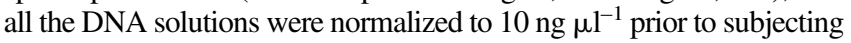
them to the two qPCR assays.

Soybean sampling, DNA isolation, and qPCR conditions. To determine the application of the two qPCR assays (Zhang et al.
1997) to detect $D$. longicolla and $D$. caulivora in commercial field samples, 10 soybean plants were collected from 11 fields affected by soybean stem canker during a survey of commercial soybean fields that was conducted in South Dakota in 2014. The soybean plants were arbitrarily collected from the 11 fields at reproductive (R2 to R4) growth stages (Fehr et al. 1971) (Table 2). Prior to DNA extraction, 10 plants from each of the fields were washed with tap water for $2 \mathrm{~min}$. Pieces (approximately $5 \mathrm{~cm}$ long) were cut from the stems of the infected soybean samples collected from each field. The pieces were surface disinfested in sodium hypochlorite $(0.05 \%)$ and then ethanol $(70 \%)$ for $1 \mathrm{~min}$ each, rinsed in sterile distilled water twice, and blotted between sterile filter paper.

Prior to DNA extraction, the stem pieces from 5 of the 10 soybean samples from each field were ground with liquid nitrogen using a mortar and pestle. DNA was isolated using the PowerLyzer PowerSoil DNA Isolation Kit (Mo Bio Laboratories Inc., Carlsbad, CA). Real-time amplifications were performed using Applied Biosystems 7900HT Fast Real-Time PCR System (Life Technologies). Each qPCR consisted of $1.6 \mu \mathrm{l}$ of template DNA, $1.0 \mu \mathrm{l}$ of $10 \mu \mathrm{M}$ forward primers, $1.0 \mu \mathrm{l}$ of $10 \mu \mathrm{M}$ reverse primers, $2 \mu \mathrm{l}$ of $100 \mathrm{nM}$ respective probe, $4.4 \mu \mathrm{l}$ of sterile distilled water, and $10 \mu \mathrm{l}$ of TaqMan Environmental Master Mix (Applied Biosystems) in $20 \mu \mathrm{l}$ of total volume. Cycling parameters for qPCR of D. longicolla and $D$. caulivora were $95^{\circ} \mathrm{C}$ for $10 \mathrm{~min}$, followed by 40 cycles of $95^{\circ} \mathrm{C}$ for $15 \mathrm{~s}$ and $60^{\circ} \mathrm{C}$ for $1 \mathrm{~min}$ (Zhang et al. 1997). Each set of reactions included DNA extracted from $D$. longicolla isolate DP01-422 and D. caulivora isolate DP00-203. The $C_{t}$ values were determined at the given threshold for the first set of samples analyzed (0.024) and subsequent ones were set to this.

The stem pieces from the remaining five soybean samples were placed on PDA (Becton, Dickinson and Company) amended to $\mathrm{pH} 4.5$ with $85 \%$ lactic acid. Plates were incubated at $25^{\circ} \mathrm{C}$ for 7 to 10 days with a photoperiod of $12 \mathrm{~h}$ daily. To perform molecular identification, eight representative isolates were selected and DNA was extracted from the mycelium scraped from the surface of 10-day-old Diaporthe cultures growing on PDA using the FastDNA Spin Kit (MP Biomedicals) (Table 2). The Diaporthe isolates were identified by amplifying and sequencing of the ITS regions using primers ITS1 and ITS2 (White et al. 1990). Analysis of the ITS sequences was performed using BLASTN searches at the GenBank nucleotide database.

Table 1. Specificity test panel for validation of quantitative polymerase chain reaction (qPCR) assay for detection of Diaporthe longicolla and D. caulivora

\begin{tabular}{|c|c|c|c|c|c|c|}
\hline \multirow[b]{2}{*}{ Isolate ID } & \multirow[b]{2}{*}{ Pathogen ${ }^{b}$} & \multirow[b]{2}{*}{ Host } & \multirow[b]{2}{*}{ Yearc } & \multirow[b]{2}{*}{ Origin } & \multicolumn{2}{|c|}{ qPCR assay $\left(C_{t}\right)$ specific to ${ }^{a}$} \\
\hline & & & & & $\overline{\text { D. longicolla }}{ }^{\mathrm{d}}$ & $\overline{\text { D. caulivora }} \mathrm{e}^{\mathrm{e}}$ \\
\hline 14-OP-PHO-7 & D. caulivora & Glycine $\max$ & 2002 & South Dakota & - & 19.51 \\
\hline 14-OP-PHO-8 & D. caulivora & G. $\max$ & 2003 & South Dakota & - & 17.70 \\
\hline 14-OP-PHO-9 & D. caulivora & G. $\max$ & 2007 & South Dakota & - & 20.28 \\
\hline 14-OP-PHO-10 & D. caulivora & G. $\max$ & 2012 & South Dakota & - & 19.85 \\
\hline 14-OP-PHO-1 & D. longicolla & G. $\max$ & 2007 & South Dakota & 20.56 & - \\
\hline 14-OP-PHO-IL-13 & D. longicolla & G. $\max$ & 2014 & Illinois & 19.60 & - \\
\hline 14-OP-PHO-IN-5 & D. longicolla & G. $\max$ & 2014 & Indiana & 18.40 & - \\
\hline 14-OP-PHO-MI-9 & D. longicolla & G. $\max$ & 2014 & Michigan & 17.84 & - \\
\hline 15-OP-SF-DIA-01 & D. gulyae & Helianthus annuus & 2014 & South Dakota & 35.77 & - \\
\hline 14-OP-MISC-1 & Glomerella sp. & G. $\max$ & 2014 & South Dakota & 35.55 & - \\
\hline 14-OP-MISC-2 & Pyrenophora tritici-repentis & Triticum aestivum & 2013 & South Dakota & 36.24 & - \\
\hline 14-OP-MISC-3 & Phialophora gregata & G. $\max$ & 2010 & South Dakota & 36.37 & - \\
\hline 14-OP-MISC-4 & Fusarium oxysporum & G. $\max$ & 2014 & South Dakota & 35.42 & - \\
\hline 14-OP-MISC-5 & F. graminearum & G. $\max$ & 2014 & South Dakota & - & - \\
\hline 14-OP-MISC-6 & F. acuminatum & G. $\max$ & 2014 & South Dakota & 36.32 & - \\
\hline
\end{tabular}

a Cycle threshold $\left(\mathrm{C}_{\mathrm{t}}\right)$ values indicate the specificity performance of the quantitative polymerase chain reaction assay when genomic DNA at $0.2 \mathrm{ng} / \mu \mathrm{l}^{-1}$ (for D. caulivora and D. longicolla) or $2 \mathrm{ng} / \mu \mathrm{l}^{-1}$ (for the other pathogens) was added to the reaction; - indicates no amplification in the qPCR assay.

b Pathogen isolates were confirmed by DNA sequencing in the study by Olson et al. (2015) and Gebreil et al. (2015).

c Year of isolation.

d Samples with $C_{t}$ values less than 35 were considered to have detectable levels of DNA with the qPCR assay (each value represents the mean of three technical replicates for $D$. longicolla).

${ }^{\mathrm{e}}$ Samples with $\mathrm{C}_{\mathrm{t}}$ values less than 40 were considered to have detectable levels of DNA with the qPCR assay (each value represents the mean of three technical replicates for D. caulivora). 
Greenhouse screening, DNA isolation, and qPCR conditions. To determine the application of the two qPCR assays (Zhang et al. 1997) on greenhouse inoculated soybean samples and phenotype for resistance to the two Diaporthe spp., nine plant introduction (PI) soybean lines were used for D. longicolla and seven PI lines for D. caulivora, based on a preliminary greenhouse study (A. Gebreil and F. Mathew, unpublished). In total, 16 PI lines were selected for screening soybean accession lines for genetic resistance and PI 518671 (Williams 82) was used as the susceptible check (Tables 2 and 3). Seed of the PI lines were obtained from the United States Department of Agriculture-Agricultural Research Service Soybean Germplasm Collection (R. Nelson, University of Illinois, Urbana).

For each experiment, soybean seed of the PI lines were sown in a potting mix (Sunshine Mix number 1; Sun Grow Horticulture Products, Belleview, WA) in 7.5-liter circular plastic pots, two plants per pot, grown for 4 weeks at $22^{\circ} \mathrm{C}$ in the greenhouse under a 12-h photoperiod with a light intensity of $450 \mu \mathrm{Em}^{-2} \mathrm{~s}^{-1}$, and watered daily. The PI lines were screened for resistance to D. longicolla and $D$. caulivora using a modified toothpick inoculation method (Keeling 1982). The trial was performed in a completely randomized design with three replicates (pots) per treatment (D. longicolla or D. caulivora isolate), and the experiment was repeated once. To obtain inoculum for the two Diaporthe spp., the most aggressive isolates of $D$. caulivora (SD-22) and D. longicolla (SD-18) identified in a previous study (A. Gebreil and F. Mathew, unpublished) were grown on PDA with sterilized wood toothpicks placed on top of the media. After 7 days of incubation, the toothpicks were removed from the PDA and inserted 2 to $3 \mathrm{~mm}$ deep into the lower stems (approximately $150 \mathrm{~mm}$ above the cotyledon) of the soybean plants that were at approximate developmental stages V3 to V4 (Fehr et al. 1971). The Diaportheinfested toothpicks were wrapped with Parafilm on the inoculated stem to avoid rapid dehydration. After inoculation, plants were kept in the greenhouse for 14 days at $22^{\circ} \mathrm{C}$ with a 12 -h photoperiod and a light intensity of $450 \mu \mathrm{Em}^{-2} \mathrm{~s}^{-1}$. For each experiment, the six plants from each PI line were pooled together and washed with tap water for $2 \mathrm{~min}$. At 14 days after inoculation, the lesion on the stem, the stem length from the soil line to the top of the plant, and the length between the nodes (internodal length) were measured. Disease severity was calculated as a percentage of stem lesion (lesion length/stem length $\times 100$ ) and internodal lesion (lesion length/internodal length $\times 100$ ). After the disease severity was measured, pieces (approximately $5 \mathrm{~cm}$ long) were cut from the infected stems and subjected to DNA extraction.

Prior to DNA extraction, the stem pieces from the pooled samples from each PI line were ground with liquid nitrogen using a mortar and pestle. The samples showed consistency in symptom development and were pooled after performing statistical analyses. No significant differences in disease severity $(P>0.05)$ were determined among inoculated soybean plants (replications). DNA was isolated from the ground material using the Wizard Genomic DNA Purification Kit (Promega Corp.). Real-time amplifications were performed using Applied Biosystems 7900HT Fast Real-Time PCR System (Life Technologies). Each qPCR consisted of $1.6 \mu \mathrm{l}$ of template DNA, $1.0 \mu \mathrm{l}$ of $10 \mu \mathrm{M}$ forward primers, $1.0 \mu \mathrm{l}$ of $10 \mu \mathrm{M}$ reverse primers, $2 \mu \mathrm{l}$ of $100 \mathrm{nM}$ respective probe, $4.4 \mu \mathrm{l}$ of sterile distilled water, and $10 \mu \mathrm{l}$

Table 2. Results from screening soybean plant introduction (PI) lines for resistance to Diaporthe caulivora using quantitative polymerase chain (qPCR)

\begin{tabular}{|c|c|c|c|c|c|c|}
\hline \multirow[b]{2}{*}{ Sample ${ }^{a}$} & \multirow[b]{2}{*}{ Origin } & \multirow[b]{2}{*}{$\mathbf{M G}^{\mathbf{b}}$} & \multirow[b]{2}{*}{$\operatorname{Stem}(\%)^{\mathrm{c}}$} & \multirow[b]{2}{*}{ Internode $(\%)^{d}$} & \multicolumn{2}{|c|}{$\begin{array}{l}\text { D. caulivora-specific } \\
\text { qPCR assay }\end{array}$} \\
\hline & & & & & $\overline{C_{t} \text { value }^{e}}$ & DNA $(\mathbf{f g})^{f}$ \\
\hline PI 518671 C (Williams 82) & United States & III & 3.9 & 27.0 & 30.86 & $495.9 \mathrm{~b}$ \\
\hline PI 612735 & China & I & 1.3 & 8.5 & 34.01 & $22.4 \mathrm{~b}$ \\
\hline PI 495831 & France & I & 3.7 & 32.1 & 32.88 & $148.4 \mathrm{~b}$ \\
\hline PI 567473 A & China & I & 2.1 & 13.1 & 35.55 & $3.5 \mathrm{~b}$ \\
\hline PI 567473 B & China & I & 5.0 & 44.0 & 34.49 & $9.8 \mathrm{~b}$ \\
\hline PI 592921 & China & I & 3.4 & 22.6 & 36.31 & $31.3 \mathrm{~b}$ \\
\hline PI 597403 A & Russia & 0 & 7.4 & 60.9 & 29.92 & $2,544.3 \mathrm{a}$ \\
\hline
\end{tabular}

a Seed of the PI soybean lines were obtained from the United States Department of Agriculture-Agricultural Research Service Soybean Germplasm Collection

(R. Nelson, University of Illinois, Urbana); PI 518671 (Williams 82) is the susceptible check.

b Maturity group.

${ }^{\mathrm{c}}$ Stem lesion is the length of the lesion expressed as a percentage of lesion produced on the stem and stem length.

${ }^{\mathrm{d}}$ Internode lesion is the length of the lesion expressed as a percentage of lesion produced on the node and nodal length.

${ }^{\mathrm{e}}$ Samples with cycle threshold $\left(\mathrm{C}_{\mathrm{t}}\right)$ values less than 40 were considered to have detectable levels of DNA with the qPCR assay (each value represents the mean of three technical replicates for $D$. caulivora).

${ }^{\mathrm{f}}$ DNA concentration of $D$. caulivora was calculated using the equation $y=(-3.667) x+34.47$, where $y=\mathrm{C}_{\mathrm{t}}$ values.

Table 3. Results from screening soybean plant introduction (PI) lines for resistance to Diaporthe longicolla using quantitative polymerase chain (qPCR)

\begin{tabular}{|c|c|c|c|c|c|c|}
\hline \multirow[b]{2}{*}{ Sample ${ }^{\mathbf{a}}$} & \multirow[b]{2}{*}{ Origin } & \multirow[b]{2}{*}{$\mathbf{M G}^{\mathbf{b}}$} & \multirow[b]{2}{*}{ Stem $(\%)^{\mathbf{c}}$} & \multirow[b]{2}{*}{ Internode $(\%)^{d}$} & \multicolumn{2}{|c|}{$\begin{array}{l}\text { D. longicolla-specific } \\
\text { qPCR assay }\end{array}$} \\
\hline & & & & & $\mathrm{C}_{\mathrm{t}}$ value $^{\mathrm{e}}$ & DNA (fg) $)^{\mathbf{f}}$ \\
\hline PI 518671 (Williams 82) & United States & III & 6.6 & 51.1 & 26.64 & $522.00 \mathrm{~b}$ \\
\hline PI $612708 \mathrm{C}$ & China & I & 6.5 & 29.0 & 28.45 & $48.17 \mathrm{~d}$ \\
\hline PI 417507 & Germany & 0 & 3.9 & 22.9 & 27.89 & $73.17 \mathrm{~d}$ \\
\hline PI 518750 & Former Serbia and Montenegro & I & 2.2 & 11.6 & 28.52 & $212.83 \mathrm{~cd}$ \\
\hline PI 511866 & China & 0 & 13.9 & 51.9 & 26.02 & $307.37 \mathrm{c}$ \\
\hline PI 507705 & Russia & 0 & 5.1 & 24.5 & 28.13 & $62.87 \mathrm{~d}$ \\
\hline PI 612715 & China & I & 13.2 & 53.9 & 24.85 & $2,872.10 \mathrm{a}$ \\
\hline PI 597403A & Russia & 0 & 1.8 & 15.3 & 29.03 & $161.37 \mathrm{~cd}$ \\
\hline
\end{tabular}

a Seed of the PI soybean lines were obtained from the United States Department of Agriculture-Agricultural Research Service Soybean Germplasm Collection

(R. Nelson, University of Illinois, Urbana); PI 518671 (Williams 82) is the susceptible check.

b Maturity group.

${ }^{\mathrm{c}}$ Stem lesion is length of the lesion expressed as a percentage of lesion produced on the stem and stem length

d Internode lesion is length of the lesion expressed as a percentage of lesion produced on the node and nodal length.

e Samples with cycle threshold $\left(\mathrm{C}_{\mathrm{t}}\right)$ values less than 35 were considered to have detectable levels of DNA with the qPCR assay (each value represents the mean of three technical replicates for $D$. longicolla).

${ }^{\mathrm{f}}$ DNA concentration of $D$. longicolla was calculated using the equation $y=(-3.427) x+34.128$, where $y=\mathrm{C}_{\mathrm{t}}$ values. 
of TaqMan Environmental Master Mix (Applied Biosystems) in $20 \mu 1$ of total volume. Cycling parameters for qPCR of D. longicolla and D. caulivora were $95^{\circ} \mathrm{C}$ for $10 \mathrm{~min}$, followed by 40 cycles of $95^{\circ} \mathrm{C}$ for $15 \mathrm{~s}$ and $60^{\circ} \mathrm{C}$ for $1 \mathrm{~min}$ (Zhang et al. 1997). Each set of reactions included DNA extracted from D. longicolla isolate DP01-422 and D. caulivora isolate DP00-203. The $\mathrm{C}_{\mathrm{t}}$ values were determined at a threshold of 0.024 .

In order to quantify $D$. longicolla and $D$. caulivora for each soybean PI line in their respective experiments, qPCR assays were performed to determine the $\mathrm{C}_{\mathrm{t}}$ values (Tables 2 and 3), and the pathogen DNA concentration corresponding to the $\mathrm{C}_{\mathrm{t}}$ values was calculated using the standard curves. For detecting $D$. longicolla and $D$. caulivora in the inoculated soybean plants and comparing the PI lines for resistance to the pathogen, the amount of sample DNA was normalized to 10 and $100 \mathrm{ng}$, respectively. The DNA content of $D$. longicolla and $D$. caulivora determined for each PI line within their respective experiments was compared using test statistics with the MIXED procedure in SAS (v 9.3; SAS Institute, Cary, NC) at $P \leq 0.05$. For each pathogen, the association between disease severity for each PI line at 14 days after inoculation of the soybean plants and the amount of DNA of $D$. longicolla and D. caulivora present in the inoculated plants was quantified with Spearman rank correlation coefficients $\left(r_{\mathrm{s}}\right)$ (Spearman 1904) using the PROC CORR procedure on SAS.

\section{Results}

Optimization of the qPCR assays to detect $D$. longicolla and D. caulivora. The primer pairs' corresponding probe sets, PL-3 and DPC-3, developed by Zhang et al. (1997), demonstrated high specificity to DNA from $D$. longicolla isolate DP01-422 and D. caulivora isolate DP00-203, which obtained $C_{t}$ values of 16 and 17 , respectively, at 1/1,000 dilutions of the fungal DNA. Three different dilutions of the fungal DNA $(1 / 1,000,1 / 10,000$, and $1 / 100,000)$, with a stock

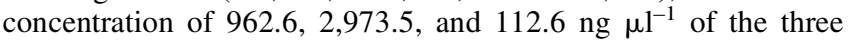
Diaporthe isolates DP01-422, DP99-030, and DP00-203, respectively, were evaluated for linear amplification. The highest concentration (1/1,000 dilution, $C_{t}$ values approximately 17) was selected for further study to determine the least amount of probe that will not be limiting. Among the five different concentrations of the probe $(50,100,150,200$, and $250 \mathrm{~nm})$ tested in the study, $100 \mathrm{~nm}$ was determined to be the optimal concentration for both the DPC 3 and PL probe $\left(C_{t}\right.$ values approximately 19$)$ because increasing probe amounts beyond $100 \mathrm{~nm}$ caused no reduction in $\mathrm{C}_{\mathrm{t}}$ values.

Application of the qPCR assays to detect $D$. longicolla and D. caulivora in soybean tissue. Low levels of both $D$. longicolla and $D$. caulivora DNA were detected in asymptomatic samples by the primer DPC-3 and PL-3 primer-probe sets with qPCR, as indicated by $C_{t}$ values ( $<35$ for both the pathogens; Fig. 1 ). In the case of symptomatic stem canker samples, one sample (Fig. 1; sample 1 in the graph) had higher levels of D. caulivora DNA $\left(C_{t}\right.$ values $\left.=24.3\right)$ but only basal levels of $D$. longicolla DNA $\left(C_{t}\right.$ values $\left.=32.2\right)$ (Fig. 1). The other sample (sample 2 in the graph) also had higher levels of $D$. caulivora DNA $\left(\mathrm{C}_{\mathrm{t}}\right.$ values $\left.=20.0\right)$ and basal levels of D. longicolla $\mathrm{DNA}\left(\mathrm{C}_{\mathrm{t}}\right.$ values $\left.=31.9\right)($ Fig. 1$)$. For the axenic plant samples, the primer DPC-3 and PL-3 primer-probe sets produced no amplification of $D$. caulivora and D. longicolla. When DNA from axenic samples spiked with DNA of $D$. caulivora and $D$. longicolla, $\mathrm{C}_{t}$ values of 18.9 and 23.1, respectively, were obtained. These $C_{t}$ values were comparable with those obtained with fungal DNA, indicating that the pathogens are likely to be detected in plant tissues with the same efficiency as pure fungal DNA (Fig. 1).

Amplification and reaction conditions for the qPCR assays. The standard curves for the two qPCR assays had correlation coefficients greater than 0.99 . The $C_{t}$ values were linear over the range of $100 \mathrm{pg}$ to $10 \mathrm{fg}$ of target DNA tested for D. longicolla and D. caulivora. Although a dilution with $1 \mathrm{fg}$ was attempted, only three of four and two of four replicates were amplified by $\mathrm{C}_{\mathrm{t}}$ values of 40 for $D$. longicolla and $D$. caulivora, respectively.

DNA of $D$. longicolla and D. caulivora were detected with qPCR at quantities over a range of $100 \mathrm{pg}$ to $10 \mathrm{fg}$. For D. caulivora, the qPCR assay detected target DNA concentrations with $\mathrm{C}_{t}$ values of 19.85 to 34.54. A linear relationship was observed between the $C_{t}$ values and the log of input template DNA concentration of $D$. caulivora isolate DP12-038, with the equation $y=(-3.667) x+34.47$. The correlation coefficient $\left(R^{2}\right)$ was 0.999 . The PCR efficiency for this assay was $87.37 \%$, based on the formula of efficiency $=$ $\left(10^{(-1 / \text { slope })}-1\right) \times 100$. For D. longicolla , the qPCR assay detected target DNA concentrations with $C_{t}$ values of 20.56 to 34.15 . A linear relationship was observed between the $C_{t}$ values and the log of input template DNA concentration of D. longicolla isolate DP12-008, with the equation $y=(-3.427) x+34.128 . R^{2}$ was 0.998 . The PCR efficiency for this assay was $95.79 \%$, based on the formula of efficiency $=\left(10^{(-1 / \text { slope })}-1\right) \times 100$.

Fungal isolates, DNA isolation, and qPCR conditions. The primer-probe set DPC-3 (Zhang et al. 1997) used for the detection of $D$. longicolla and $D$. caulivora was highly specific because it did not amplify PCR products from the DNA of nontarget fungal species (Table 1). The DPC-3 and PL-3 primer-probe sets did not produce amplification of $D$. longicolla and $D$. caulivora beyond $\mathrm{C}_{\mathrm{t}}$ values of 35 and 40, respectively; hence, these values were selected as the cut-off $\mathrm{C}_{\mathrm{t}}$ values for the two assays.

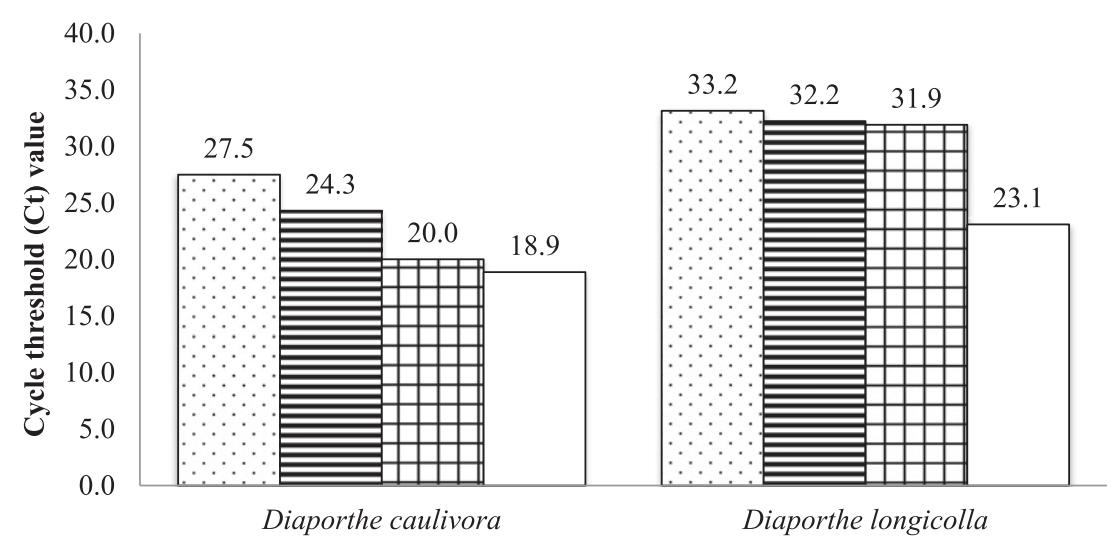

$\square$ Asymptomatic $\quad$ ESample (1) $\boxplus$ Sample (2) $\square$ Spiked

Fig. 1. Ability of TaqMan primer-probe sets DPC-3 and PL-3 to detect Diaporthe caulivora and D. Iongicolla in plant tissue samples. Bars from left to right: asymptomatic stems, canker tissue sample 1, canker tissue sample 2, and axenic plant material spiked with fungal DNA. Pathogens were not detectable in axenically growth soybean seedlings. Samples with cycle threshold $\left(\mathrm{C}_{t}\right)$ values less than 35 were considered to have detectable levels of DNA with the quantitative polymerase chain reaction (qPCR) assay (each value represents the mean of three technical replicates for $D$. Iongicolla). Samples with $C_{t}$ values less than 40 were considered to have detectable levels of DNA with the qPCR assay (each value represents the mean of three technical replicates for $D$. caulivora). 
Soybean sampling, DNA isolation, and qPCR conditions. To diagnose soybean plants collected from commercial fields in South Dakota, both the culture-based isolation of the causal fungus from the stem-canker-affected samples on PDA and qPCR assays were used. Overall, $D$. longicolla was found in 10 of the 11 soybean plant samples from commercial fields, with $\mathrm{C}_{\mathrm{t}}$ values of 20.11 to 34.28 (Table 4). In contrast, D. caulivora was found in five samples but only one with $\mathrm{C}_{\mathrm{t}}$ value $<35$ (Table 4 ). The isolations on PDA were attempted twice to cross-check the results from the two qPCR assays.

Based on the diagnosis test results using qPCR, soybean plants symptomatic of stem canker were associated with both $D$. longicolla and $D$. caulivora (Table 4 ). However, in a few instances, when symptomatic plants were plated out on PDA, only D. longicolla was isolated and not $D$. caulivora. The $D$. longicolla isolated on PDA was confirmed by a BLASTN search of GenBank performed for the ITS sequences of the isolates, which showed that the best match was Phomopsis longicolla (syn. D. longicolla) strain STAM-35 (GenBank accession number AY745021), with identities ranging from 98 to $100 \%$. For example, the sample collected from Clay County (F-11) had typical symptoms such as reddish-brown lesions and sunken cankers near the leaf node. The sample was detected to be positive for D. longicolla $\left(\mathrm{C}_{\mathrm{t}}\right.$ values $\left.=21.62\right)$, which was also confirmed by isolation on PDA (Table 4). However, D. caulivora $\left(\mathrm{C}_{\mathrm{t}}\right.$ values $\left.=31.54\right)$ was detected in low levels in the infected sample and not isolated on PDA. In contrast, a sample from Miner County (F-77) with no stem canker symptoms was detected to be positive for $D$. longicolla $\left(C_{t}\right.$ values $\left.=29.79\right)$, although the pathogen was not isolated on PDA (Table 4).

Greenhouse screening, DNA isolation, and qPCR conditions. To evaluate for genetic resistance to $D$. longicolla and D. caulivora, the qPCR assay developed in this study was used to determine the amount of DNA of D. longicolla and D. caulivora present in stems of the different soybean PI lines (Tables 2 and 3).

For $D$. caulivora, significant differences in genetic resistance were observed among the seven PI lines based on the amount of DNA detected (least significant difference $[\mathrm{LSD}]=849.04, F$ value $=9.74$, $P<0.0003)$. Low levels of pathogen DNA were detected in all PI lines except PI 597403A, as compared with the susceptible check, PI 518671 (Williams 82), indicating that these accession lines are resistant (Table 2). However, there were a few accession lines which had high pathogen DNA compared with the susceptible check; for example, the amount of DNA determined with qPCR was highest for PI $597403(2,544.3 \mathrm{fg})$ and significantly different from all the PI lines, including the susceptible check, PI 518671 (Williams 82) (495.9 fg) (Table 2). The correlation between percent internode lesion and the amount of pathogen DNA was significant and strong $\left(r_{\mathrm{s}}=0.77, P=0.0448\right)$ in the greenhouse experiment. In addition, the correlation between percent stem lesion and the amount of pathogen DNA was significant and strong $\left(r_{\mathrm{s}}=0.82, P=0.0266\right)$.

For $D$. longicolla, significant differences in genetic resistance were observed among the nine PI lines based on the amount of DNA detected $(\mathrm{LSD}=203.36, F$ value $=199.66, P<0.0001)$. Low pathogen DNA was detected in PI 612708C, PI 417507, and PI 507705 compared with the susceptible check, PI 518671 (Williams 82), indicating that these three accession lines are resistant (Table 3 ). The amount of pathogen DNA present in PI $612715(2,872.10 \mathrm{fg})$ was significantly greater than in the susceptible check, PI 518671 (Williams 82) (522.00 fg) (Table 3). The correlation between percent internode lesion and the amount of pathogen DNA was not significant at $P \leq 0.05\left(r_{\mathrm{s}}=0.59, P=0.1225\right)$ in the greenhouse experiment. Additionally, the correlation between percent stem lesion and the amount of pathogen DNA was not significant at $P \leq 0.05\left(r_{\mathrm{s}}=0.61\right.$, $P=0.1057)$.

\section{Discussion}

In this study, two qPCR assays (PL-3 and DPC-3) developed by Zhang et al. (1997) were optimized to quantify D. longicolla and D. caulivora in soybean plant samples. The two assays required maceration of soybean plants in liquid nitrogen using a mortar and pestle, followed by use of commercial DNA extraction kits to obtain genomic DNA, and application of primers specifically designed to detect $D$. longicolla and D. caulivora in real-time PCR using TaqMan probe chemistry. The probe concentration and DNA template dilution rate were optimized in the two qPCR assays to detect $D$. longicolla and $D$. caulivora in the subsequent studies. The two assays could detect as little as $10 \mathrm{fg}$ of pure genomic DNA of the D. longicolla and D. caulivora isolates. In the qPCR assays using fungal cultures, the two assays were specific to $D$. longicolla and $D$. caulivora, given that neither primer set amplified PCR products from DNA of each other or other fungal species commonly associated with soybean and other hosts. The qPCR assays were validated to detect and quantify $D$. longicolla and $D$. caulivora in the soybean samples collected from commercial soybean fields that exhibited typical symptoms of stem canker. Additionally, the qPCR assays were used to evaluate stem resistance to $D$. longicolla and $D$. caulivora among soybean accession lines. Significant differences were observed among the accession lines for stem resistance to D. longicolla $(P<0.0001)$ and $D$. caulivora $(P<0.0003)$ in their respective greenhouse experiments based on the amount of DNA of the two pathogens, as determined using qPCR.

Given that DNA preparation can be a challenge, Zhang et al. (1997, 1999) used purified plasmids for validating the TaqMan assays in their study. However, we chose to directly isolate the DNA

Table 4. Diagnostic results for commercial soybean samples collected from different counties in South Dakota using the quantitative polymerase chain reaction (qPCR) assay and traditional isolation on potato dextrose agar ${ }^{\mathrm{a}}$

\begin{tabular}{|c|c|c|c|c|c|c|}
\hline \multirow[b]{2}{*}{ Sample ID } & \multirow[b]{2}{*}{ County } & \multicolumn{2}{|c|}{ Diaporthe longicolla } & \multicolumn{2}{|c|}{ Diaporthe caulivora } & \multirow[b]{2}{*}{ Symptoms $^{\mathrm{d}}$} \\
\hline & & Isolation & $C_{t}$ value $^{b}$ & Isolation & $\mathrm{C}_{\mathrm{t}}$ value $^{\mathrm{c}}$ & \\
\hline F-8 & Union & Positive & 34.28 & Negative & - & RB lesion \\
\hline F-11 & Clay & Positive & 21.62 & Negative & 31.54 & RB lesion; sunken cankers \\
\hline F-52 & Spink & Positive & 33.40 & Negative & 36.49 & Zone lines on root \\
\hline F-55 & Brown & Positive & 33.58 & Negative & 37.50 & RB lesion \\
\hline F-77 & Miner & Negative & 29.79 & Negative & - & No-symptoms \\
\hline F-93 & Davison & Positive & 20.11 & Negative & - & RB lesion; sunken cankers \\
\hline F-101 & Hanson & Positive & 31.38 & Negative & - & RB lesion \\
\hline F-103 & McCook & Negative & 32.18 & Negative & 37.18 & No-symptoms \\
\hline F-116 & Minnehaha & Positive & 29.86 & Negative & - & Plant wilting, dead \\
\hline F-125 & Lake & Negative & 31.90 & Negative & - & No-symptoms \\
\hline F-143 & Miner & Positive & 35.78 & Negative & 37.06 & RB lesion \\
\hline
\end{tabular}

a Pathogens were isolated from commercial soybean samples on potato dextrose agar and identified by colony morphology and sequencing of the internal transcribes spacer region. Each cycle threshold $\left(\mathrm{C}_{t}\right)$ value is the average of three technical replicates; - indicates no amplification in the qPCR assay.

${ }^{b}$ Samples with $C_{t}$ values less than 35 were considered to have detectable levels of DNA with the qPCR assay (each value represents the mean of three technical replicates for Diaporthe longicolla).

${ }^{c}$ Samples with $C_{t}$ values less than 40 were considered to have detectable levels of DNA with the qPCR assay (each value represents the mean of three technical replicates for D. caulivora).

d Description of symptoms as observed in the field; $\mathrm{RB}=$ reddish-brown. 
from soybean plants infected by Diaporthe spp. that were sampled from commercial fields or soybean plants that were inoculated in the greenhouse. There are several advantages to using genomic DNA over plasmid DNA: (i) the genomic DNA can be used as a standard for amplification of any gene product (in contrast, the plasmid DNA require unique pools that have to be designed for each gene of interest); (ii) the heterogeneous nature of complementary DNA is better represented by genomic DNA than plasmid DNA; and (iii) generation of plasmid DNA as an external standard would require multiple-step dilutions to achieve useable copy numbers and this can introduce small errors at each amplification step during PCR (Yun et al. 2006). Using genomic DNA, our study applied and optimized two of the qPCR assays (PL-3 and DPC-3) to detect $D$. longicolla and $D$. caulivora in soybean plants, which were designed by Zhang et al. (1997) for detection of Diaporthe spp. in soybean seed. However, the third primer-probe set (PL5) designed by Zhang et al. (1997) did not amplify the D. longicolla isolate (DP01-422) used in our study. This possibly may be due to the sequence variation of the ITS region in D. longicolla isolates used in this study and the isolates used by Zhang et al. (1997) to design the primer-probe sets. A future evaluation of this probe set using multiple $D$. longicolla isolates is expected to resolve this question.

To be able to optimize the qPCR assays using genomic DNA to detect $D$. longicolla and $D$. caulivora in soybean tissue, the DNA isolation methods were adjusted to each plant tissue to avoid contamination from secondary metabolites. For example, although lysis with a sodium dodecyl sulfate-containing buffer followed by salt and alcohol precipitation resulted in clean DNA most often from the greenhouse soybean plants, the contamination, especially at $230 \mathrm{~nm}$, was quite high (e.g., absorbance at $260 / 230 \mathrm{~nm}$ usually $<1.0$ ) for the samples from the commercial soybean fields, which suggested that the preparations were not free of proteins and polyphenolicpolysaccharide compounds. Thus, for the soybean plants sampled from the commercial fields, a sample kit containing a DNA-binding column was used. Further, potential inhibition of DNA quality or PCR amplification was evaluated by spiking the genomic DNA of $D$. longicolla and $D$. caulivora on soybean plants under laboratory conditions, and successful amplification was observed (equivalent to that observed when pure fungal DNA was used as template). This indicates the ability to use the PL-3 and DPC-3 assays without additional purification, which is of benefit to plant disease diagnosticians for accurate disease diagnosis, as well as to soybean breeders who would potentially evaluate several hundred accession lines to determine host resistance to the two Diaporthe spp.

In order to validate the two qPCR assays for D. longicolla and D. caulivora and quantify the pathogens, soybean samples were collected from commercial soybean fields in South Dakota with characteristic northern stem canker symptoms such as reddish-brown lesions and sunken cankers on the lower stem and node. Although the soybean samples had different levels of the pathogen DNA, the two qPCR assays were more sensitive than the traditional isolation of the pathogens on PDA. For example, the PL-3 assay detected D. longicolla $\left(\mathrm{C}_{\mathrm{t}}\right.$ values $\left.=21.62\right)$ from the soybean sample collected from Clay County (F-11), which was also confirmed by traditional isolation on PDA (Table 2). However, D. caulivora $\left(\mathrm{C}_{\mathrm{t}}\right.$ values $=$ 31.54) was detected by the DPC-3 qPCR assay at low levels in the same infected soybean sample. This shows that the DPC-3 qPCR assay was sensitive to low levels of colonization by $D$. caulivora, although the pathogen was not isolated by plating the infected soybean samples on PDA. There was amplification and detection of D. longicolla on the asymptomatic plants sampled from three fields, as indicated by $\mathrm{C}_{\mathrm{t}}$ values $<35$ for $D$. longicolla (Table 4 ). This may be because $D$. longicolla can be endophytic on soybean and other plant hosts (Botella and Diez 2011; Gomes et al. 2013; Murali et al. 2006), and the qPCR assay was able to detect the pathogen.

The most effective method to manage stem canker on soybean is the development and planting of resistant cultivars (Backman et al. 1985; Hartman et al. 1999). However, when the soybean genotypes are screened for genetic resistance under greenhouse conditions or natural conditions, symptom expression from the method of inoculation or pathogen variability can cause problems in accurately determining resistance levels. This is where qPCR assays can be helpful, particularly when development of a useful system to rate for host resistance can be challenging. In this study, the DNA levels of D. longicolla and $D$. caulivora quantified by the respective qPCR assays clearly distinguished resistant cultivars from the susceptible PI 518671 (Williams 82 ). For $D$. caulivora, low pathogen DNA was detected in all PI lines except PI 597403A, indicating that these accession lines are resistant when compared with the susceptible check, PI 518671 (Williams 82) (Table 2). In contrast, for D. longicolla, low pathogen DNA was detected in PI 612708C, PI 417507, and PI 507705 when compared with the susceptible check, PI 518671 (Table 3). Based on correlation coefficients, the levels of $D$. caulivora DNA were significantly and strongly correlated with disease severity based on percent stem lesion $\left(r_{\mathrm{s}}=0.82, P=0.0266\right)$ and percent internode lesion $\left(r_{\mathrm{s}}=0.77, P=\right.$ $0.0448)$ in the greenhouse experiment. However, the levels of D. longicolla DNA did not correlate strongly with disease severity based on percent stem lesion $\left(r_{\mathrm{s}}=0.61, P=0.1057\right)$ and percent internode lesion $\left(r_{\mathrm{s}}=0.59, P=0.1225\right)$ in the greenhouse experiment. It is possible that, despite the greenhouse conditions being optimum for infection by $D$. longicolla on the soybean accession lines, low disease severity was observed and possibly dead cells were quantified by the PL-3 qPCR assay for D. longicolla. Thus, it is important to consider that, when using qPCR to screen host genotypes for resistance, the primers can only detect and quantify the target pathogens. The qPCR assays cannot distinguish DNA from living versus dead cells of the pathogens (Chilvers et al. 2007). Thus, it is important to consider this limitation that, when using qPCR to screen host genotypes for resistance, the assays may be quantifying the target pathogens, irrespective of where living or dead cells of the pathogen are present.

In summary, the qPCR assays PL-3 and DPC-3, designed by Zhang et al. (1997), have been optimized for rapid and accurate quantification of D. longicolla and D. caulivora in soybean plant tissues. Accurate species identification is a critical step for developing management strategies for the diseases caused by these pathogens, particularly because there are differences in pathogen characteristics among and within Diaporthe spp., including D. longicolla and D. caulivora (Li et al. 2010; Lu et al. 2010; A. Gebreil and F. Mathew, unpublished). Although qPCR methods do have the limitation of the upper and lower limits of the standard curve, the limitations are much less stringent in situations where visual diagnosis or culture-based methods may not be practical. This is definitely true in the case of Diaporthe spp., where identification of the causal pathogen based on visual diagnosis of the stem-canker-affected plants and culture-based methods are not reliable (van Rensburg et al. 2006). Given the sensitivity of the qPCR assays PL-3 and DPC-3 (Zhang et al. 1997) that were optimized in this study when evaluating soybean plants exhibiting a range of susceptibility to $D$. longicolla and $D$. caulivora, they can be used to screen soybean genotypes for resistance in field experiments in future.

\section{Acknowledgments}

This research was supported by the South Dakota Soybean Research and Promotion Council (Sioux Falls, SD) and the South Dakota Agricultural Experimental Station (Hatch Project H527-14). We acknowledge the use of the South Dakota State University Functional Genomics Core Facility supported, in part, by the National Science Foundation/Experimental Program to Stimulate Competitive Research (NSF/EPSCoR) Grant Number 0091948 and by the State of South Dakota for this study. We thank R. Nelson and his staff for providing soybean seed for the greenhouse study to screen for resistance to the two Diaporthe spp.; and A. Gebreil, P. Bartlett, A. Micijevic, A. Weber, T. Olson, S. Mages, P. Okello, L. Hyronimus, A. Baggett, and K. Ghimire for their assistance and support in this study

\section{Literature Cited}

Athow, K. L. 1973. Fungal diseases. Pages 459-489 in: Soybeans: Improvement, Production and Uses, 2nd ed. Agron. Monogr. Vol. 16. B. E. Caldwell, ed. ASA, CSSA, and SSSA, Madison, WI.

Athow, K. L., and Caldwell, R. M. 1954. A comparative study of Diaporthe stem canker and pod and stem blight of soybean. Phytopathology 44:319-325.

Backman, P. A., Weaver, D. B., and Morgan-Jones, G. 1985. Soybean stem canker: An emerging disease problem. Plant Dis. 69:641-647.

Botella, L., and Diez, J. J. 2011. Phylogenic diversity of fungal endophytes in Spanish stands of Pinus halepensis. Fungal Divers. 47:9-18. 
Chase, T. E. 2011. Occurrence of Northern stem canker in first soybean plantings following Conservation Reserve in South Dakota. (Abstr.) Phytopathology 101:S31.

Chilvers, M. I., du Toit, L. J., Akamatsu, H., and Peever, T. L. 2007. A real-time, quantitative PCR seed assay for Botrytis spp. that cause neck rot of onion. Plant Dis. 91:599-608

Cui, Y. L., Duan, C. X., Wang, X. M., Li, H. J., and Zhu, Z. D. 2009. First report of Phomopsis longicolla causing soybean stem blight in China. Plant Pathol. 58:799.

Dunleavy, J. M. 1969. Consequence of intensive cultural practices on soybean diseases in the Corn Belt. Pages 35-40 in: Disease Consequences of Intensive and Extensive Culture of Field Crops. J. A. Browning, ed. Spec. Rep. 64. Iowa Agric. Home Econ. Exp. Stn. Iowa State University, Ames.

Fehr, W. R., Caviness, C. E., Burmood, D. T., and Pennington, J. S. 1971. Stage of development descriptions for soybeans, Glycine max (L.). Merrill. Crop Sci. 11: 929-931.

Fernández, F. A., Phillips, D. V., Russin, J. S., and Rupe, J. C. 1999. Stem canker. Pages 33-35 in: Compendium of Soybean Diseases, 4th ed. G. L. Hartman, J. B. Sinclair, and J. C. Rupe, eds. American Phytopathological Society, St. Paul, MN.

Gebreil, A., Micijevic, A., Weber, A., Hyronimus, L., and Mathew, F. 2015. Characterization of Diaporthe species infecting soybeans (Glycine max L.) in South Dakota. Page 362 in: Proc. 100th Anniv. Meet. S. D. Acad. Sci. Vol. 94. Oacoma, SD. http://www.sdaos.org/wp-content/uploads/pdfs/2015/362.pdf

Gomes, R. R., Glienke, C., Videira, S. I. R., Lombard, L., Groenewald, J. Z., and Crous, P. W. 2013. Diaporthe: A genus of endophytic, saprobic and plant pathogenic fungi. Persoonia 31:1-41.

Harrington, T. C., Steimel, J., Workneh, F., and Yang, X. B. 2000. Molecular identification of fungi with vascular discoloration of soybean in the north central United States. Plant Dis. 84:83-89.

Hartman, G. L., Sinclair, J. B., and Rupe, J. C., eds. 1999. Compendium of Soybean Diseases, 4th ed. American Phytopathology Society, St. Paul, MN.

Hildebrand, A. A. 1956. Observations on stem canker and pod and stem blight of soybeans in Ontario. Can. J. Bot. 34:577-599.

Hobbs, T. W., Schmitthenner, A. F., and Kuter, G. A. 1985. A new Phomopsis species from soybean. Mycologia 77:535-544.

Keeling, B. L. 1982. A seedling test for resistance to soybean stem canker caused by Diaporthe phaseolorum var. caulivora. Phytopathology 72:807-809.

Kucharek, T., Whiteside, J., and Brown, E. 1983. Melanose and stem end rot of citrus. Plant pathology fact sheet. Florida Cooperative Extension Service, Institute of Food and Agricultural Sciences, University of Florida, Gainesville.

Lehman, S. G. 1922. Pod and stem blight of soybean. J. Elisha Mitchell Sci. Soc. 38:13.

Lehman, S. G. 1923. Pod and stem blight of soybean. Ann. Mo. Bot. Gard. 10: 111-178.

Li, S., Boykin, D., Sciumbato, G., Wrather, A., Shannon, G., and Sleper, D. 2009. Reaction of soybean cultivars to Phomopsis seed decay in the Mississippi Delta, 2007. Plant Dis. Manage. Rep. 3:FC096.

Li, S., Hartman, G. L., and Boykin, D. L. 2010. Aggressiveness of Phomopsis longicolla and other Phomopsis spp. on soybean. Plant Dis. 94:1035-1040.
Lu, X., Robertson, A. E., Byamukama, E. Z., and Nutter, F. W., Jr. 2010 Evaluating the importance of stem canker of soybean in Iowa. Plant Dis. 94: 167-173.

Mathew, F. M., Alananbeh, K., Jordahl, J. G., Meyer, S. M., Castlebury, L. A., Gulya, T. J., and Markell, S. G. 2015a. Phomopsis stem canker: A reemerging threat to sunflower (Helianthus annuus) in the United States. Phytopathology 105:990-997.

Mathew, F. M., Castlebury, L. A., Alananbeh, K., Jordahl, J. G., Taylor, C. A., Meyer, S. M., Lamppa, R. S., Pasche, J. A., and Markell, S. G. 2015b. Identification of Diaporthe longicolla on dry edible pea, dry edible bean, and soybean in North Dakota. Plant Health Prog. doi:10.1094/PHP-RV-14-0045

Murali, T. S., Suryanarayanan, T. S., and Geeta, R. 2006. Endophytic Phomopsi species: Host range and implications for diversity estimates. Can. J. Microbiol. 52:673-680.

Olson, T. R., Gebreil, A., Micijevic, A., Bradley, C. A., Wise, K. A., Mueller, D. S., Chilvers, M. I., and Mathew, F. M. 2015. Association of Diaporthe longicolla with black zone lines on mature soybean plants. Plant Health Prog. doi:10.1094/PHP-RS-15-0020

Santos, J. M., Vrandečić, K., Ćosić, J., Duvnjak, T., and Phillips, A. J. L. 2011 Resolving the complex of Diaporthe/Phomopsis species on soybean in Croatia. Persoonia 27:9-19.

Spearman, C. 1904. The proof and measurement of association between two things. Am. J. Psychol. 15:72-101.

Timmer, L. W., and Fucik, J. E. 1976. The relationship of rainfall distribution, fruit growth, and fungicide application to the incidence of melanose on grapefruit in Texas. Plant Dis. Rep. 60:565-568.

Udayanga, D., Castlebury, L. A., Rossman, A. Y., Chukeatirote, E., and Hyde, K. D. 2014. The Diaporthe sojae species complex: Phylogenetic re-assessment of pathogens associated with soybean, cucurbits and other field crops. Fungal Biol. 119:383-407.

van Rensburg, J. C. J., Lamprecht, S. C., Groenewald, J. Z., Castlebury, L. A. and Crous, P. W. 2006. Characterization of Phomopsis spp. associated with die-back of rooibos (Aspalathus linearis) in South Africa. Stud. Mycol. 55:65-74.

White, T. J., Bruns, T., Lee, S., and Taylor, J. 1990. Amplification and direct sequencing of fungal and ribosomal RNA genes for phylogenetics. Pages 315-322 in: PCR Protocols: A Guide to Methods and Applications. Academic Press, Inc., San Diego, CA.

Whiteside, J. O. 1977. Sites of action of fungicides in the control of Citrus melanose. Phytopathology 67:1067-1072.

Yun, J. J., Heisler, L. E., Hwang, I. I., Wilkins, O., Lau, S. K., Hyrcza, M., Jayabalasingham, B., Jin, J., McLaurin, J., Tsao, M. S., and Der, S. D. 2006. Genomic DNA functions as a universal external standard in quantitative realtime PCR. Nucleic Acids Res. 34:e85.

Zhang, A. W., Hartman, G. L., Curio-Penny, B., Pedersen, W. L., and Becker, K. B. 1999. Molecular detection of Diaporthe phaseolorum and Phomopsis longicolla from soybean seeds. Phytopathology 89:796-804.

Zhang, A. W., Hartman, G. L., Riccioni, L., Chen, W. D., Ma, R. Z., and Pedersen, W. L. 1997. Using PCR to distinguish Diaporthe phaseolorum and Phomopsis longicolla from other soybean fungal pathogens and to detect them in soybean tissues. Plant Dis. 81:1143-1149. 